\title{
Recessive Resistance Governed by a Major Quantitative Trait Locus Restricts Clover Yellow Vein Virus in Mechanically but Not Graft-Inoculated Cultivated Soybeans
}

\author{
Junya Abe, ${ }^{1}$ Yongzhi Wang, ${ }^{2,3}$ Tetsuya Yamada, ${ }^{1}$ Masako Sato, ${ }^{1}$ Takuya Ono, ${ }^{1}$ Go Atsumi, ${ }^{4}$ Jun Abe, ${ }^{1}$ \\ M. R. Hajimorad, ${ }^{2}$ and Kenji S. Nakahara ${ }^{1, \dagger}$ \\ ${ }^{1}$ Research Faculty of Agriculture, Hokkaido University, Sapporo 060-8589, Japan \\ ${ }^{2}$ Department of Entomology and Plant Pathology, University of Tennessee, Knoxville, TN 37996, U.S.A. \\ 3 Jilin Academy of Agricultural Sciences, 1363 Caiyu Street, Changchun 130033, Jilin, China \\ ${ }^{4}$ National Institute of Advanced Industrial Science and Technology, Sapporo, Hokkaido, Japan
}

Accepted 3 March 2019.

\begin{abstract}
Clover yellow vein virus (CIYVV) infects and causes disease in legume plants. However, here, we found that CIYVV isolate No. 30 (CIYVV-No.30) inefficiently multiplied or spread via cell-tocell movement in mechanically inoculated leaves of a dozen soybean (Glycine max) cultivars and resulted in failure to spread systemically. Soybean plants also had a similar resistance phenotype against additional CIYVV isolates. In contrast, all but one of 24 tested accessions of wild soybeans (G. soja) were susceptible to CIYVV-No.30. Graft inoculation of cultivated soybean TK780 with CIYVV-No.30-infected wild soybean B01167 scion resulted in systemic infection of the cultivated soybean rootstock. This suggests that, upon mechanical inoculation, the cultivated soybean inhibits CIYVVNo.30, at infection steps prior to the systemic spread of the virus, via vascular systems. Systemic infection of all F1 plants from crossing between TK780 and B01167 and of 68 of 76 F2 plants with CIYVV-No.30 indicated recessive inheritance of the resistance. Further genetic analysis using 64 recombinant inbred lines between TK780 and B01167 detected one major quantitative trait locus, designated $d-c v$, for the resistance that was positioned in the linkage group D1b (chromosome 2). The mapped region on soybean genome suggests that $d-c v$ is not an allele of the known resistance genes against soybean mosaic virus.
\end{abstract}

Keywords: virus-plant interactions

The cultivated soybean (Glycine max) is an important crop worldwide, supplying food products such as boiled and

${ }^{\dagger}$ Corresponding author: K. S. Nakahara; knakahar@res.agr.hokudai.ac.jp

Funding: This work was supported by Japan Society for the Promotion of Science KAKENHI (grant numbers 25450055 and $16 \mathrm{H} 04879$ to K. S. Nakahara), the Novartis Foundation Japan for the Promotion of Science (to K. S. Nakahara), and the Asahi Glass Foundation (to K. S. Nakahara).

*The $e$-Xtra logo stands for "electronic extra" and indicates that three supplementary figures and three supplementary tables are published online.

The author(s) declare no conflict of interest.

(C) 2019 The American Phytopathological Society fermented soybean (edamame and natto), soybean milk, tofu and soy sauce, vegetable oil, and proteins for human consumption and animal feed. Its economic contribution worldwide is estimated conservatively at $\$ 48.6$ billion per year (Wilson 2008). It is a diploidized tetraploid $(2 n=40)$ species, classified in the subgenus Soja in the legume family Fabaceae. The subgenus Soja includes members of $G$. soja, which is thought to be an immediate wild ancestor of cultivated soybean, and the domestication is supposed to have occurred 3,000 to 5,000 years ago (Cregan 2008). Wild soybean is distributed in China, the Russian Far East region, Korea, Taiwan, and Japan (Lu 2004). Since progeny derived from crosses between cultivated and wild soybean are fully fertile, wild soybean has been used as a genetic resource to confer useful traits on soybean cultivars.

As many as 112 viruses are known to infect, naturally or experimentally, soybean plants. Among these, 46 have been isolated from field soybeans and are currently a concern or could potentially be a problem in soybean production (Hill and Whitham 2014). Soybean mosaic virus belongs to the genus Potyvirus in the family Potyviridae. Soybean mosaic virus (SMV) is the most prevalent virus that causes significant crop losses in soybean production (Hajimorad et al. 2018; Saghai Maroof et al. 2008). Members of the genus Potyvirus, including SMV, are single-stranded, positive-sense RNA viruses, forming filamentous particles with 2,000 copies of coat protein (CP). The genomic RNA is about $10 \mathrm{~kb}$ and encodes a large open reading frame (ORF), from which a polyprotein is produced and processed into a dozen mature proteins by three viralencoded proteases (Ivanov et al. 2014). A small ORF, pipo, is embedded in the $P 3$ cistron at -1 frame (Chung et al. 2008). The $P 3$ cistron additionally produces frameshift products with or without the pipo-encoded peptide, P3N-PIPO and P3N-ALT (Hagiwara-Komoda et al. 2016), which are involved in viral cell-to-cell movement (Wei et al. 2010; Wen and Hajimorad 2010) via transcriptional slippage at the $\mathrm{G}_{1-2} \mathrm{~A}_{6-7}$ motif upstream of pipo (Hagiwara-Komoda et al. 2016; Olspert et al. 2015; Rodamilans et al. 2015). Potyvirus is the largest genus of plant RNA viruses (Gibbs and Ohshima 2010) and members of the genus cause diseases in diverse crops. In addition to SMV, 18 members are able to infect soybean; however, only nine have been isolated from field-grown soybeans (Hill and Whitham 2014). Peanut mottle virus (Bays et al. 1986), bean common 
mosaic virus (Zhou et al. 2014), and bean yellow mosaic virus (BYMV) (Campos et al. 2014) are, at least, associated with soybean diseases under field conditions. Clover yellow vein virus (ClYVV) is closely related to BYMV but had not been considered to be a causal agent of soybean disease until an isolate (ClYVV-Gm) was isolated recently from field-grown soybeans in South Korea (Shin et al. 2014).

ClYVV was initially isolated from white clover (Trifolium repens) and causes chlorotic and necrotic diseases in legume plants, including broad bean (Vicia fava) and pea (Pisum sativum) (Bos et al. 1974; Sasaya et al. 1997; Tracy et al. 1992). ClYVV had not been clearly distinguished from BYMV by comparison of their host ranges and reactions as well as serological studies until nucleotide sequences of their $C P$ were determined and compared (Tracy et al. 1992; Uyeda et al. 1991). Pea plants were shown to possess three resistance loci, cyv1, cyv2, and Cyn1, against ClYVV (Andrade et al. 2007; Choi et al. 2012; Ravelo et al. 2007); cyv1 and cyv2 inhibit systemic infection of CIYVV and are recessively inherited, and cyv2 encodes an eukaryotic initiation factor 4E (Andrade et al. 2009). The $P 1$ protein is a virulence determinant of ClYVV in peas carrying cyv2 (Nakahara et al. 2010). Cynl is a semidominant gene that does not inhibit infection of ClYVV but induces a hypersensitive response (HR)-like systemic lethal necrosis via perception of ClYVV P3N-PIPO (Atsumi et al. 2009, 2016). We recently provided evidence that P3N-PIPO qualitatively and quantitatively determines virulence of ClYVV in peas carrying either cyvl or Cynl and provides a consistent gradation of virulence for ClYVV isolates No. 30, 90-1, and I89-1 in these resistant peas (Atsumi et al. 2016; Choi et al. 2013; Miyashita et al. 2016).

There is no published study regarding resistance against ClYVV in soybean cultivars. However, three inheritably dominant resistant loci, $R s v 1, R s v 3$, and $R s v 4$, against SMV have been identified in cultivated soybeans (Whitham et al. 2016). To the best of our knowledge, no recessively inherited resistance in soybean cultivars against SMV has been reported to date, though existence of recessive resistance against another potyvirus, peanut mottle virus, has been reported (Hajimorad et al. 2018; Hill and Whitham 2014). Rsv1 confers extreme resistance (ER) against a majority of SMV strains (Hajimorad and Hill 2001). The Rsvl locus located on chromosome 13 is multigenic with genes encoding nucleotide binding-leucine rich repeat proteins (NB-LRR) (Hayes et al. 2004; Wen et al. 2013). Two SMV-encoded proteins, helpercomponent proteinase (HC-Pro) and P3, are the target of recognition by the Rsvl-associated genes (Eggenberger et al. 2008; Hajimorad et al. 2008; Wen et al. 2013). The Rsv3 belongs to a coiled-coil class of NB-LRR resistance genes (Suh et al. 2011) that targets cylindrical inclusion (CI) for recognition (Seo et al. 2009; Zhang et al. 2009). This gene mediates local HR or ER against avirulent SMV strains (Seo et al. 2009; Zhang et al. 2009). The Rsv4 belongs to an unidentified class of resistance genes that restricts SMV to inoculated leaves without apparent induction of HR (Ilut et al. 2016; Khatabi et al. 2012; Saghai Maroof et al. 2010). The SMV determinant for virulence in soybean carrying Rsv4 has been mapped to P3 (Chowda-Reddy et al. 2011; Khatabi et al. 2012; Wang et al. 2015).

In this study, we found that cultivated and wild soybeans are resistant and susceptible to ClYVV, respectively. The genetic analyses using $\mathrm{F} 1$ and $\mathrm{F} 2$ progenies and recombinant inbred lines (RILs) derived from a cross between a cultivated soybean cultivar and a wild soybean line revealed that resistance in cultivated soybean is recessively inherited and governed by one major quantitative trait locus (QTL) on chromosome 2, apart from the three loci conferring resistance against SMV.

\section{RESULTS}

Cultivated soybean genotypes restrict CIYVV infection to limited foci in inoculated leaves.

Based on the uidA gene expressing $\beta$-glucuronidase (GUS) assay, ClYVV-No.30-GUS (CIYVV No. 30 harboring the uidA gene expressing GUS) was detected in inoculated leaves of a number of soybean genotypes, regardless of carrying the anti-SMV resistant genes ( $R s v 1, R s v 4$, and $3 g G 2)$ or not ( $r s v 1$, $r s v 4$, and $-3 g G 2$ ), albeit in limited and restricted foci (Fig. 1). In none of the biolistically inoculated cultivated soybean (Glycine max) was the virus detected in the noninoculated leaves, whether assayed for GUS expression or detection of the CP by enzyme-linked immunosorbent assay (ELISA) (Supplementary Table S1). We then mechanically inoculated cultivated soybean 'Williams' with sap extract derived from ClYVV-No.30infected broad bean leaves in the absence of GUS. None of the 28 inoculated plants developed symptoms of infection on inoculated or noninoculated leaves, and ELISA failed to detect $\mathrm{CP}$ in the noninoculated leaves. Thus, failure of CIYVV-No.30GUS to move systemically in cultivated soybean is not a consequence of GUS-tagging of the genome, as shown for another potyvirus (German-Retana et al. 2000). This result is further supported by the observations that ClYVV-No.30-GUS was able to move systemically in noninoculated leaves from all five biolistically inoculated broad bean cultivar Windsor leaves and five of eight from wild soybean accession B01167. We here note that the virus was detected in veinal tissues of inoculated leaves of wild soybean B01167 but not at all in cultivated soybean leaves (Fig. 1).

We then mechanically inoculated ClYVV No. 30 tagged with green fluorescent protein (ClYVV-No.30-GFP) onto cultivated and wild soybeans and compared its spread by continuously monitoring GFP fluorescence over time (Fig. 2A). ClYVVNo.30-GFP gradually spread in inoculated leaves of cultivated soybean TK780. However, cell-to-cell movement seemed repressed in soybean TK780 when compared with movement in inoculated wild soybean B01167 leaves. Consistently, viral CP accumulated to a relatively lower level in inoculated leaves of cultivated soybeans at 7 days postinoculation (dpi) than in wild soybean leaves (Fig. 2B). We further monitored GFP fluorescence in systemically infected parts of cultivated and wild soybeans (Fig. 2C). No GFP signal derived from ClYVVNo.30-GFP infection was observed in noninoculated parts of cultivated soybean TK780, despite the presence of fluorescence from GFP in slices of stems in the upper part (cut 1), root (cut 3 ), and petiole of inoculated leaves (cut 2) of a wild soybean (B01167). Western blotting and reverse transcription (RT)-PCR assays to detect viral CP and genomic RNA in noninoculated upper leaves, respectively, confirmed that soybean cultivars Williams 82, Tanishidaizu, and TK780 were not infected systemically with ClYVV-No.30-GFP (Fig. 3; Table 1). Taken together, all the cultivated soybeans tested were able to reduce either the multiplication or cell-to-cell movement of CIYVV No. 30 in inoculated leaves, or both, and to restrict it to inoculated leaves only.

\section{Cultivated soybeans show resistance to all tested CIYVV isolates.}

To examine whether the resistance of cultivated soybeans is specific to isolate No. 30 of ClYVV or if it is broad, we inoculated three soybean cultivars, Tanishidaizu, TK780, and Williams 82, with three CIYVV isolates, ClYVV-No.30-GFP, I89-1 (ClYVV-I89-1) and 90-1 (ClYVV-90-1) (Table 1; Fig. 3; Supplementary Figs. S1 and S2). No symptoms developed on the three soybean cultivars inoculated regardless of the CIYVV isolates, and GFP and viral CP were not detected in any of the 
noninoculated upper leaves, except for the TK780 plants inoculated with ClYVV-I89-1. An RT-PCR assay to detect viral genomic RNA also confirmed that none of the three ClYVV isolates systemically infected the inoculated cultivars, except for the TK780 plants inoculated with ClYVV-I89-1, in which that virus spread to noninoculated systemic leaves of all four inoculated plants. However, we did not detect, by western immunoblotting, $\mathrm{CP}$ in two of four of these plants, and in those where viral CP was detected, the level of viral accumulation was still lower compared with the level in the wild soybean tissues infected with ClYVV-I89-1. None of TK780 plants developed pronounced symptoms, although one plant developed very mild symptoms at a later date (Table 1 ), indicating that TK780 may even be partially resistant to ClYVV-I89-1. Taken together, we conclude that cultivated soybeans commonly have resistance against ClYVV or that ClYVV is not adapted well to cultivated soybeans. Interestingly, phylogenetic analysis of Clover yellow vein virus with members belonging to nine other virus species within the Potyvirus genus, of which members infect soybeans naturally or experimentally (Hill and Whitham 2014), showed that Clover yellow vein virus and its close relative, Bean yellow mosaic virus, forms a clade that is very distant from the well-adapted Soybean mosaic virus.

\section{Contrasting susceptibility}

\section{of wild soybeans against CIYVV.}

In contrast to cultivated soybeans, most of the wild soybeans inoculated were susceptible to ClYVV. When 24 accessions of wild soybeans were inoculated with ClYVV-No.30-GFP, all but one accession, B00197, developed various systemic symptoms, including vein clearing, mosaic, and necrotic spot on noninoculated upper leaves (Table 1). We confirmed systemic infection by observing fluorescence from GFP and detecting viral $\mathrm{CP}$ in noninoculated leaves of some of the accessions by western immunoblotting (Table 1; Figs. 2, 3, and 4). Wild soybean accession B00092 plants, however, did not express GFP fluorescence or symptoms on noninoculated leaves until 28 dpi (Table 1). B04009 and B08034 plants developed relatively mild symptoms compared with those of B01167 and B03015 (Fig. 4). These results indicate that wild soybeans are generally susceptible to ClYVV, though, among those tested, some were less susceptible than others and one was resistant to systemic infection.

\section{Graft-inoculation of cultivated soybean with CIYVV No.30 results in systemic infection.}

Grafting between wild and cultivated soybean is compatible. To examine where ClYVV infection is blocked, we directly inoculated ClYVV-No.30-GFP into the vascular system of cultivated soybean by grafting, using ClYVV-No.30-GFP infected wild soybean (B01167) as a scion. One month after grafting, the GFP signal was detected in leaves of the cultivated soybean rootstock parts grown from the axillary bud (Fig. 5A). Accumulation of ClYVV-No.30-GFP genomic RNA was confirmed by RT-PCR in these leaves (Fig. 5A), indicating the systemic spread of ClYVV-No.30-GFP in the cultivated soybean parts upon graft-inoculation. We were concerned that the systemic spread of ClYVV-No.30-GFP in cultivated soybean was not due to the inoculation manner but rather to the emergence of an adaptive ClYVV No. 30 mutant that may have
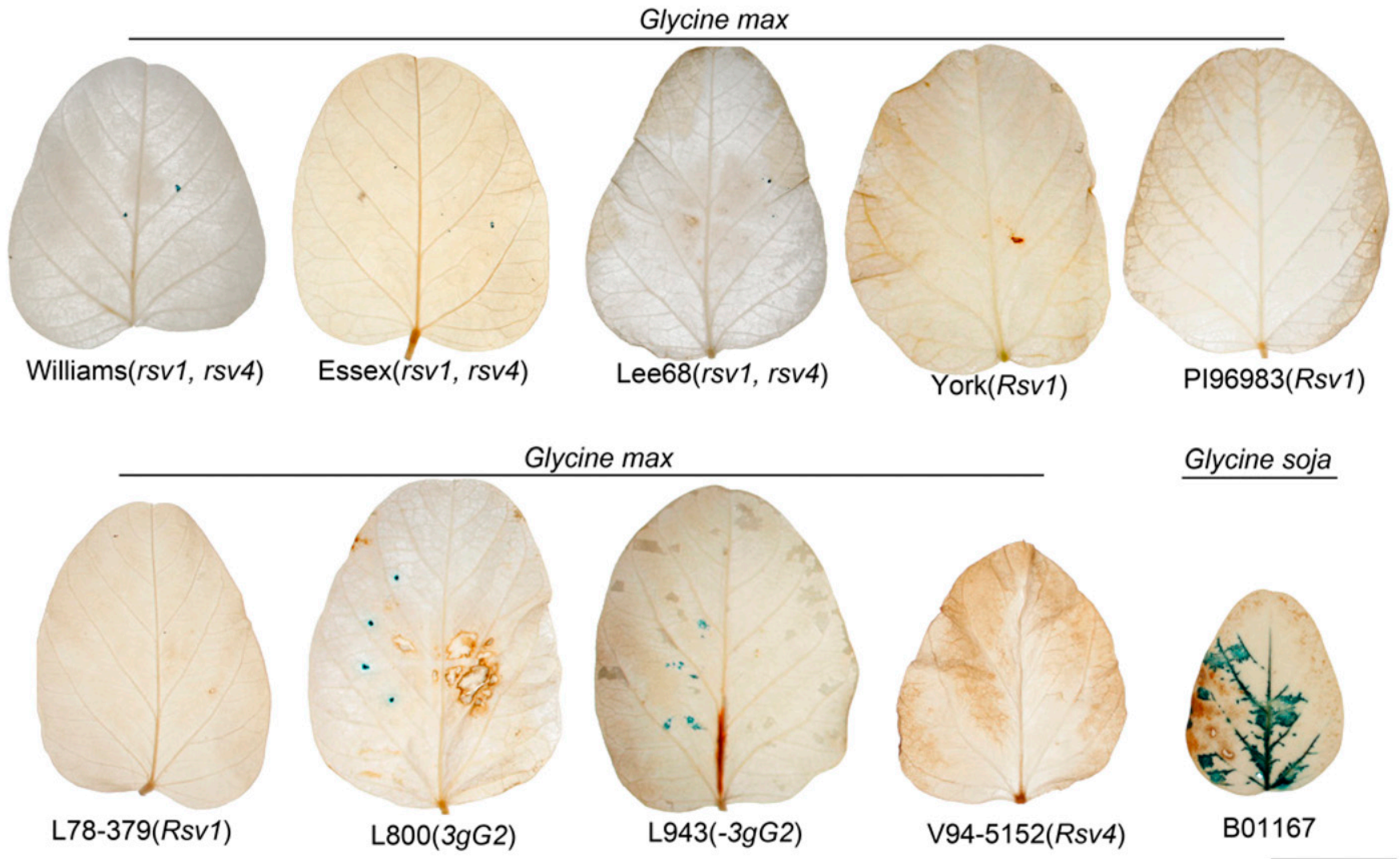

Glycine max

\section{Glycine soja}
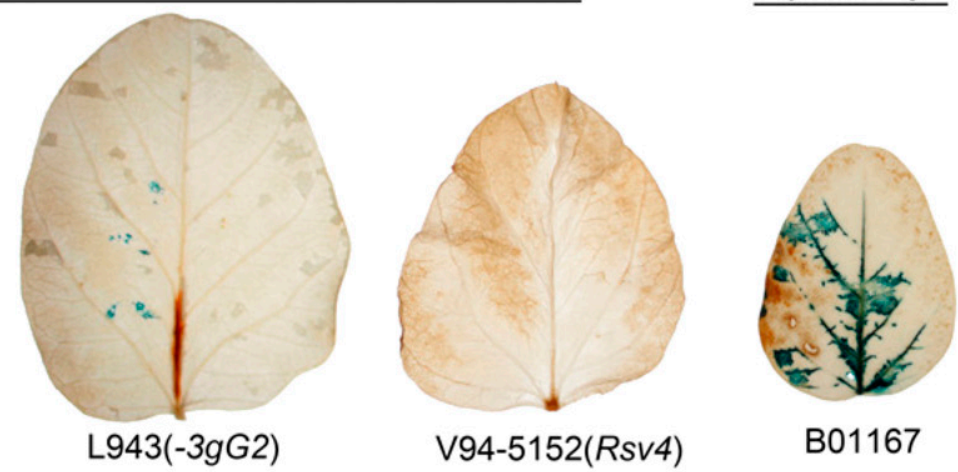

Fig. 1. $\beta$-Glucuronidase (GUS)-histochemical analysis of clover yellow vein virus (ClYVV) infection in biolistically inoculated soybean leaves. For inoculation, a full-length infectious cDNA clone of ClYVV isolate No. 30 harboring GUS was delivered biolistically into fully developed attached primary leaves of approximately 2-week-old soybean seedlings maintained at $22^{\circ} \mathrm{C}$. Leaves were analyzed histochemically for GUS expression at 21 days postinoculation. Note the presence of GUS in leaf veins of wild soybean B01167 and its absence in veins of all leaves from cultivated soybean genotypes. Scale bar $=2 \mathrm{~cm}$. 
emerged during continuous forced inoculation from the ClYVV-No.30-GFP-infected wild soybean scion serving as the inoculum source. This possibility was examined by two experiments. First, we removed the grafted wild soybean (scion) 1 week after graft-inoculation and investigated ClYVV-No.30GFP infection 1 and 2 months afterward. Both the GFP signal and ClYVV No. 30 genomic RNA were still detected in the cultivated soybean parts (Fig. 5B). Second, ClYVV-No.30-GFP that systemically infected cultivated soybean leaves (tentatively designated ClYVV-TK) was back-inoculated onto cultivated and wild soybean and broad bean. ClYVV-TK failed to infect cultivated soybean though, as expected, it infected wild
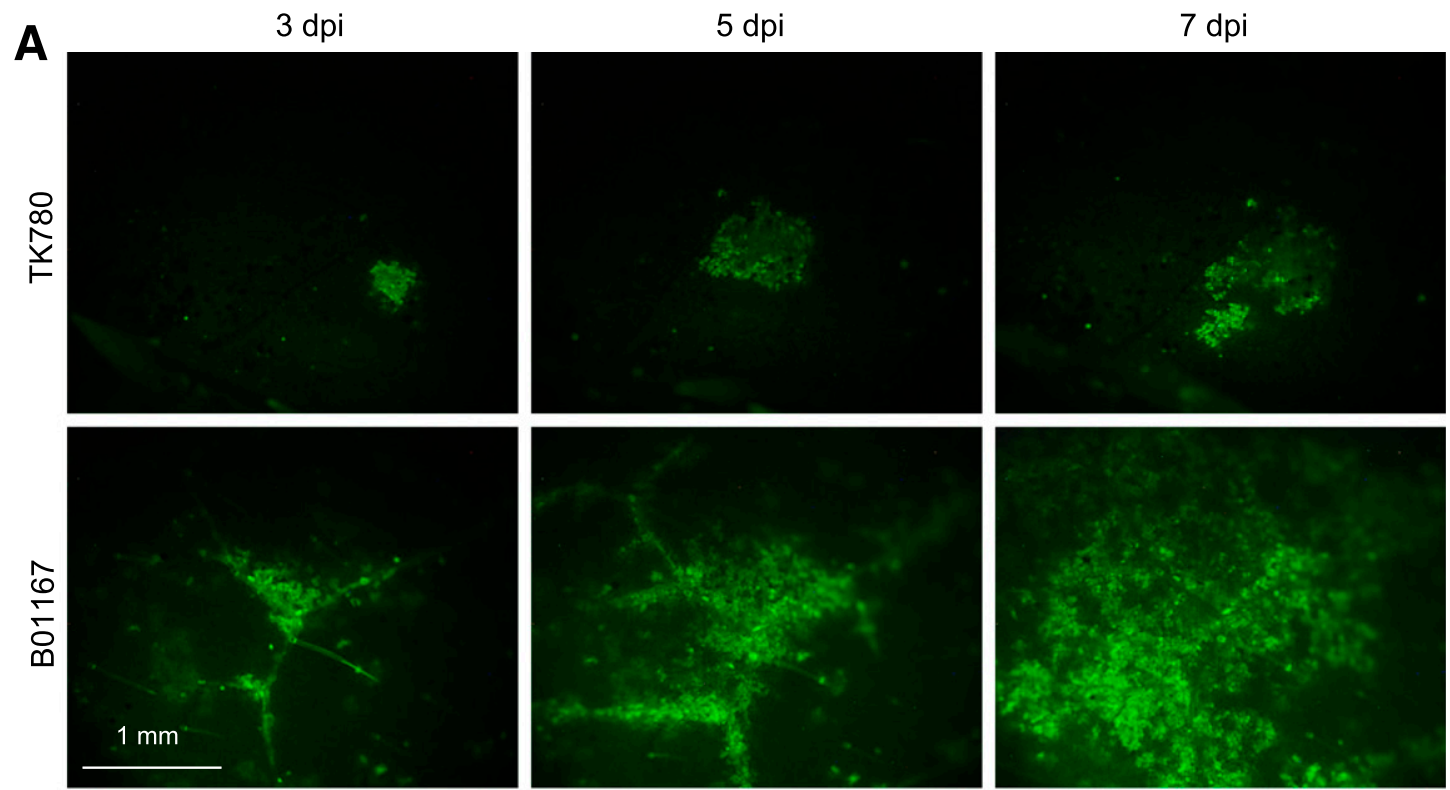

G. $\max$

G. soja

B
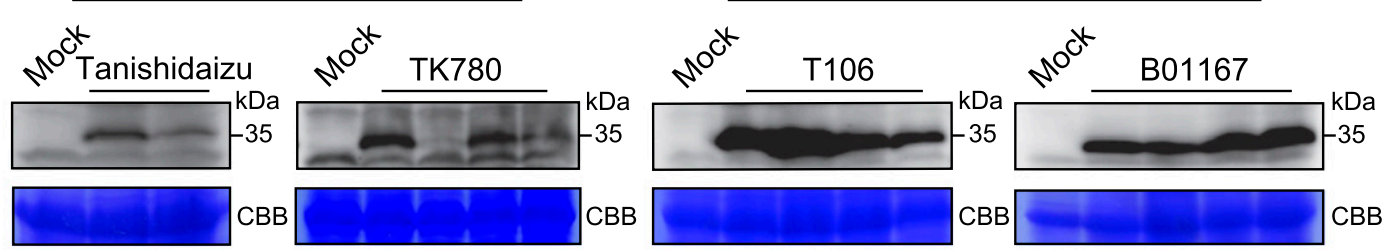

C
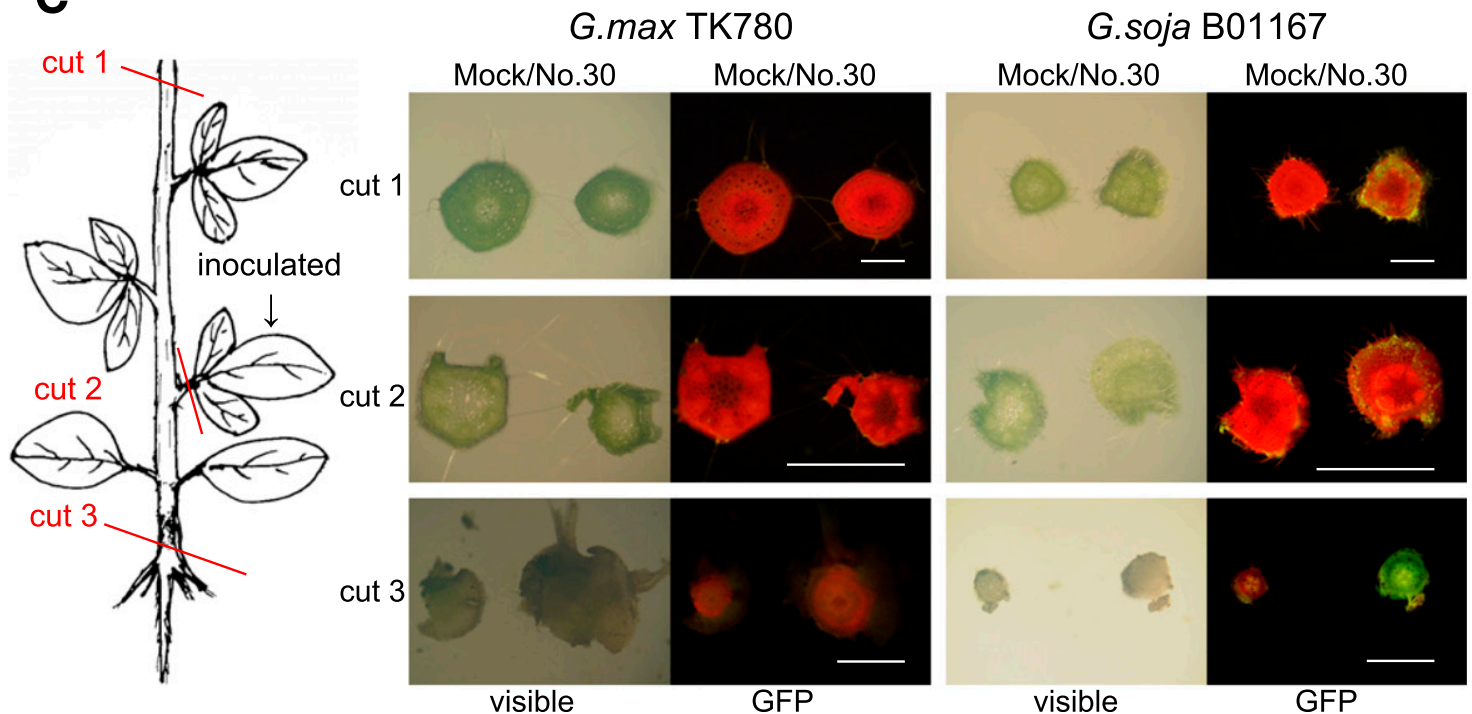

Fig. 2. A, Clover yellow vein virus (ClYVV) spread in ClYVV isolate No. 30 green fluorescent protein (GFP)-inoculated cultivated soybean and wild soybean plants. B, Accumulation of ClYVV coat protein (CP) in inoculated leaves at 7 days postinoculation (dpi) was investigated by Western blotting. Coomassie brilliant blue (CBB) gel, shown in lower panels, is the loading control. C, Systemic spread of ClYVV-No.30-GFP in cultivated soybean and wild soybean inoculated plants monitored for GFP fluorescence expression at $28 \mathrm{dpi}$. GFP signal derived from ClYVV-No.30-GFP was observed in slices of stem at the upper part (cut 1), root (cut 3), and petiole of inoculated leaves (cut 2) of a wild soybean (line B01167) but not in those of cultivated soybean cultivar TK780. Scale bars $=1 \mathrm{~mm}$. 
soybean and broad bean systemically (Fig. 5C), displaying similar disease phenotypes comparable to the original ClYVVNo.30-GFP-induced symptoms. The nucleotide sequence of the ClYVV-TK genomic RNA was determined and analyzed. No mutation was detected in the region encoding the polyprotein when compared with that of ClYVV-No.30-GFP that infected wild soybean. However, when compared with the sequences of the infectious cDNA clone (DDBJ/ENA/GenBank accession number AB011819), both ClYVV-TK and ClYVVNo.30-GFP in wild soybean had the same nonsynonymous single mutation (Supplementary Fig. S3C). We concluded that the graft-inoculation of ClYVV No. 30 infects systemically
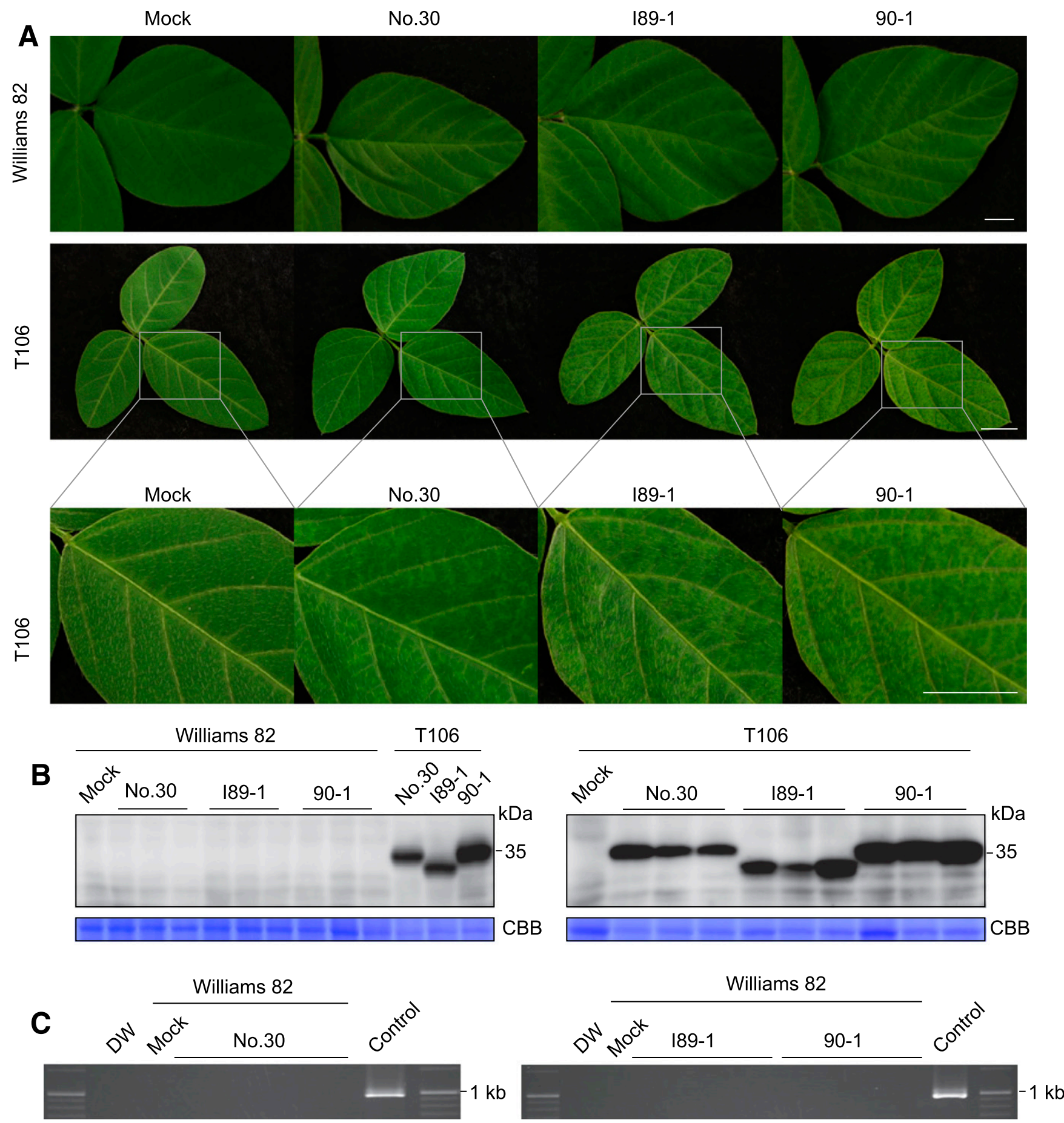

Fig. 3. Reactions of cultivated soybean Williams 82 and wild soybean line T106 mechanically inoculated with three isolates of clover yellow vein virus (ClYVV) (No.30-GFP [green fluorescent protein], I89-1, and 90-1). A, Noninoculated upper leaves were photographed at 21 days postinoculation (dpi). Scale bars $=10 \mathrm{~mm}$. B, Western blotting analysis to detect coat protein (CP) of ClYVV in samples from noninoculated leaves at $21 \mathrm{dpi}$, using anti-CP rabbit polyclonal antiserum. It should be noted that ClYVV CP was not detected in any samples from cultivated soybean Williams 82 . In contrast, CP was detected from all noninoculated leaves of wild soybean T106 inoculated on primary leaves with any of the three ClYVV isolates. Coomassie brilliant blue (CBB)-stained gel is shown as a loading control (lower panel). C, Reverse transcription (RT)-PCR analysis of RNA extractions from cultivated soybean Williams 82 at 28 dpi amplifying part of the nuclear inclusion protein b (NIb) region of the ClYVV genome. Control is RT-PCR with an RNA extract from wild soybean line T106 at 28 dpi. DW is a product of RT-PCR without RNA extract from a sample. 
cultivated soybean rootstocks. Thus, failure of ClYVV to move systemically in the mechanically inoculated cultivated soybean is likely due to inhibition of CIYVV infection at one or more steps before systemic spread via vascular systems.

\section{Resistance against CIYVV in cultivated soybean is recessively inherited.}

Further experiments were done to genetically characterize the contrasting reactions of cultivated and wild soybeans against ClYVV. To determine whether the mode of inheritance for resistance in cultivated soybean is recessive or dominant, cultivated soybean TK780 was crossed with wild soybean B01167, and the F1 and F2 progeny plants were mechanically inoculated with ClYVV-No.30-GFP. As a result, ClYVV-
No.30-GFP spread to noninoculated leaves and caused systemic symptoms in all the F1 plants at $14 \mathrm{dpi}$, comparable to the susceptibility of wild soybeans (Table 1). However, the inoculated F2 plants showed varied reactions; 40 of the 76 inoculated plants developed systemic symptoms within $14 \mathrm{dpi}$, and an additional 14 showed systemic symptoms at $21 \mathrm{dpi}$. Eight of 76 inoculated F2 plants were not infected systemically with ClYVV-No.30-GFP, at least through 28 dpi. The above results with $\mathrm{F} 2$ plants were obtained by two independent inoculation tests in which each test showed similar results. These inoculation tests with F1 and F2 plants suggest that resistance against ClYVV in cultivated soybean is recessively inherited. The ratio of the resistant and susceptible F2 plants to systemic infection was 8:68. The segregating ratio was not conformed to

Table 1. Reactions of wild soybean (Glycine soja) and cultivated soybean (G. max) plants and F1 and F2 progeny derived from a cross between the two species to three strains of clover yellow vein virus $(\mathrm{ClYVV})^{\mathrm{a}}$

\begin{tabular}{|c|c|c|c|c|c|c|c|c|c|c|}
\hline \multirow[b]{2}{*}{ Species } & \multicolumn{5}{|c|}{ Number of plants which show symptoms } & \multirow[b]{2}{*}{ GFP $^{\mathbf{b}}$} & \multirow[b]{2}{*}{ Western blot } & \multirow[b]{2}{*}{ RT-PCR } & \multirow[b]{2}{*}{ Symptom $^{c}$} & \multirow[b]{2}{*}{ Total infected } \\
\hline & Line & 7 dpi & 14 dpi & $21 \mathrm{dpi}$ & $28 \mathrm{dpi}$ & & & & & \\
\hline & \multicolumn{10}{|c|}{ ClYVV-No.30-GFP } \\
\hline \multirow{24}{*}{ G. soja } & T106 & $0 / 9$ & 9/9 & 9/9 & 9/9 & $9 / 9$ & $9 / 9$ & $\mathrm{nt}$ & $++(\mathrm{M}, \mathrm{VC})$ & $9 / 9$ \\
\hline & B00046 & $0 / 3$ & $3 / 3$ & $3 / 3$ & $3 / 3$ & $3 / 3$ & $3 / 3$ & $\mathrm{nt}$ & $++(\mathrm{VC})$ & $3 / 3$ \\
\hline & B00090 & $3 / 3$ & $3 / 3$ & $3 / 3$ & $3 / 3$ & $3 / 3$ & $3 / 3$ & $\mathrm{nt}$ & $++(\mathrm{VC})$ & $3 / 3$ \\
\hline & B00092 & $0 / 5$ & $0 / 5$ & $0 / 5$ & $4 / 5$ & $4 / 5$ & $4 / 5$ & $\mathrm{nt}$ & $+(\mathrm{VC})$ & $4 / 5$ \\
\hline & B00197 & $0 / 3$ & $0 / 3$ & $0 / 3$ & $0 / 3$ & $0 / 3$ & $0 / 3$ & $\mathrm{nt}$ & No symptom & $0 / 3$ \\
\hline & B00225 & $0 / 3$ & $3 / 3$ & $3 / 3$ & $3 / 3$ & $3 / 3$ & $3 / 3$ & nt & $+++(\mathrm{M}, \mathrm{VC})$ & $3 / 3$ \\
\hline & B01160 & $0 / 2$ & $2 / 2$ & $2 / 2$ & $2 / 2$ & $2 / 2$ & $2 / 2$ & $\mathrm{nt}$ & $++(\mathrm{M}, \mathrm{VC}, \mathrm{NS})$ & $2 / 2$ \\
\hline & B02280 & $0 / 3$ & $3 / 3$ & $3 / 3$ & $3 / 3$ & $3 / 3$ & $3 / 3$ & $\mathrm{nt}$ & $++(\mathrm{VC})$ & $3 / 3$ \\
\hline & В03015 & $0 / 3$ & $3 / 3$ & $3 / 3$ & $3 / 3$ & $3 / 3$ & $3 / 3$ & $\mathrm{nt}$ & $++(\mathrm{M}, \mathrm{VC})$ & $3 / 3$ \\
\hline & B03037 & $0 / 3$ & $1 / 3$ & $3 / 3$ & $3 / 3$ & $3 / 3$ & $3 / 3$ & $\mathrm{nt}$ & $+(\mathrm{VC})$ & $3 / 3$ \\
\hline & B04009 & $0 / 3$ & $3 / 3$ & $3 / 3$ & $3 / 3$ & $3 / 3$ & $3 / 3$ & $\mathrm{nt}$ & $+(\mathrm{VC})$ & $3 / 3$ \\
\hline & B04114 & $0 / 4$ & $4 / 4$ & $4 / 4$ & $4 / 4$ & $4 / 4$ & $4 / 4$ & $\mathrm{nt}$ & $+++(\mathrm{M}, \mathrm{VC})$ & $4 / 4$ \\
\hline & B04158 & $0 / 4$ & $4 / 4$ & $4 / 4$ & $4 / 4$ & $4 / 4$ & $4 / 4$ & $\mathrm{nt}$ & $+++(\mathrm{M}, \mathrm{VC})$ & $4 / 4$ \\
\hline & B05023 & $0 / 10$ & $1 / 10$ & $7 / 10$ & $10 / 10$ & $10 / 10$ & $10 / 10$ & $\mathrm{nt}$ & $+\sim++(\mathrm{VC})$ & $10 / 10$ \\
\hline & B06086 & $0 / 4$ & $4 / 4$ & $4 / 4$ & $4 / 4$ & $4 / 4$ & $4 / 4$ & $\mathrm{nt}$ & $++(\mathrm{M}, \mathrm{VC})$ & $4 / 4$ \\
\hline & B06098 & $0 / 5$ & $5 / 5$ & $5 / 5$ & $5 / 5$ & $5 / 5$ & $5 / 5$ & nt & $++(\mathrm{M}, \mathrm{VC})$ & $5 / 5$ \\
\hline & B07126 & $0 / 4$ & $4 / 4$ & $4 / 4$ & $4 / 4$ & $4 / 4$ & $4 / 4$ & nt & $+++(\mathrm{M}, \mathrm{VC}, \mathrm{NS})$ & $4 / 4$ \\
\hline & B07164 & $0 / 4$ & $3 / 4$ & $4 / 4$ & $4 / 4$ & $4 / 4$ & $4 / 4$ & $\mathrm{nt}$ & $++(\mathrm{VC})$ & $4 / 4$ \\
\hline & B08034 & $0 / 4$ & $2 / 4$ & $4 / 4$ & $4 / 4$ & $4 / 4$ & $4 / 4$ & $\mathrm{nt}$ & $+(\mathrm{VC})$ & $4 / 4$ \\
\hline & B08040 & $0 / 2$ & $2 / 2$ & $2 / 2$ & $2 / 2$ & $2 / 2$ & $2 / 2$ & $\mathrm{nt}$ & $++(\mathrm{M}, \mathrm{VC})$ & $2 / 2$ \\
\hline & B08045 & $0 / 3$ & $3 / 3$ & $3 / 3$ & $3 / 3$ & $3 / 3$ & $3 / 3$ & $\mathrm{nt}$ & $++(\mathrm{M}, \mathrm{VC})$ & $3 / 3$ \\
\hline & B09092 & $0 / 4$ & $0 / 4$ & $4 / 4$ & $4 / 4$ & $4 / 4$ & $4 / 4$ & $\mathrm{nt}$ & $++(\mathrm{VC})$ & $4 / 4$ \\
\hline & B09117 & $0 / 2$ & $0 / 2$ & $2 / 2$ & $2 / 2$ & $2 / 2$ & $2 / 2$ & $\mathrm{nt}$ & $+(\mathrm{VC})$ & $2 / 2$ \\
\hline & B01167 & $0 / 6$ & $6 / 6$ & $6 / 6$ & $6 / 6$ & $6 / 6$ & $6 / 6$ & $\mathrm{nt}$ & $++++(\mathrm{M}, \mathrm{VC}, \mathrm{NS})$ & $6 / 6$ \\
\hline \multirow[t]{3}{*}{ G. $\max$} & Tanishidaizu & $0 / 6$ & $0 / 6$ & $0 / 6$ & $0 / 6$ & $0 / 6$ & $0 / 6$ & $0 / 6$ & No symptom & $0 / 6$ \\
\hline & Williams 82 & $0 / 3$ & $0 / 3$ & $0 / 3$ & $0 / 3$ & $0 / 3$ & $0 / 3$ & $0 / 3$ & No symptom & $0 / 3$ \\
\hline & TK780 & $0 / 4$ & $0 / 4$ & $0 / 4$ & $0 / 4$ & $0 / 4$ & $0 / 4$ & $0 / 4$ & No symptom & $0 / 4$ \\
\hline \multirow{3}{*}{ G. soja $\times$ G. $\max ^{\mathrm{d}}$} & F1 & $0 / 8$ & $8 / 8$ & $8 / 8$ & $8 / 8$ & $8 / 8$ & $8 / 8$ & $\mathrm{nt}$ & +++ & $8 / 8$ \\
\hline & $\mathrm{F} 2$ & $0 / 76$ & $40 / 76$ & $54 / 76$ & $68 / 76$ & $68 / 76$ & NT & nt & Variable & $68 / 76$ \\
\hline & \multicolumn{10}{|c|}{ ClYVV-I89-1 } \\
\hline \multirow[t]{4}{*}{ G. soja } & T106 & $3 / 3$ & $3 / 3$ & $3 / 3$ & $3 / 3$ & - & $3 / 3$ & $\mathrm{nt}$ & $+++(\mathrm{M}, \mathrm{VC})$ & $3 / 3$ \\
\hline & B03015 & $4 / 4$ & $4 / 4$ & $4 / 4$ & $4 / 4$ & - & $4 / 4$ & $\mathrm{nt}$ & $++++(\mathrm{M}, \mathrm{VC}, \mathrm{NS})$ & $4 / 4$ \\
\hline & B04158 & $3 / 4$ & $4 / 4$ & $4 / 4$ & $4 / 4$ & - & $4 / 4$ & $\mathrm{nt}$ & $++++(\mathrm{M}, \mathrm{VC}, \mathrm{NS})$ & $4 / 4$ \\
\hline & B01167 & $2 / 4$ & $4 / 4$ & $4 / 4$ & $4 / 4$ & - & $4 / 4$ & nt & $++++(\mathrm{M}, \mathrm{VC}, \mathrm{NS})$ & $4 / 4$ \\
\hline \multirow[t]{4}{*}{ G. $\max$} & Tanishidaizu & $0 / 3$ & $0 / 3$ & $0 / 3$ & $0 / 3$ & - & $0 / 3$ & $0 / 3$ & No symptom & $0 / 3$ \\
\hline & Williams 82 & $0 / 4$ & $0 / 4$ & $0 / 4$ & $0 / 4$ & - & $0 / 4$ & $0 / 4$ & No symptom & $0 / 4$ \\
\hline & TK780 & $0 / 4$ & $0 / 4$ & $0 / 4$ & $1 / 4$ & - & $3 / 4$ & $4 / 4$ & $+(\mathrm{M}) 1 / 4$ & $4 / 4$ \\
\hline & \multicolumn{10}{|c|}{ ClYVV-90-1 } \\
\hline \multirow[t]{4}{*}{ G. soja } & T106 & $0 / 3$ & $2 / 3$ & $3 / 3$ & $3 / 3$ & - & $3 / 3$ & nt & $+++(\mathrm{M}, \mathrm{VC})$ & $3 / 3$ \\
\hline & B03015 & $0 / 2$ & $2 / 2$ & $2 / 2$ & $2 / 2$ & - & $2 / 2$ & $\mathrm{nt}$ & $+++(\mathrm{M}, \mathrm{VC})$ & $2 / 2$ \\
\hline & B04158 & $0 / 4$ & $0 / 4$ & $0 / 4$ & $2 / 4$ & - & $2 / 4$ & $\mathrm{nt}$ & $+(\mathrm{VC})$ & $2 / 4$ \\
\hline & B01167 & $0 / 7$ & $0 / 7$ & $5 / 7$ & $5 / 7$ & - & $5 / 7$ & nt & $+\sim+++(\mathrm{M}, \mathrm{VC})$ & $5 / 7$ \\
\hline \multirow[t]{3}{*}{ G. $\max$} & Tanishidaizu & $0 / 3$ & $0 / 3$ & $0 / 3$ & $0 / 3$ & - & $0 / 3$ & $0 / 3$ & No symptom & $0 / 3$ \\
\hline & Williams 82 & $0 / 4$ & $0 / 4$ & $0 / 4$ & $0 / 4$ & - & $0 / 4$ & $0 / 4$ & No symptom & $0 / 4$ \\
\hline & TK780 & $0 / 4$ & $0 / 4$ & $0 / 4$ & $0 / 4$ & - & $0 / 4$ & $0 / 4$ & No symptom & $0 / 4$ \\
\hline
\end{tabular}


the 3:1 ratio (Chi square test: $\chi^{2}=8.4912, P=0.003569$ ), indicating that two or more host factors might be involved in the inhibition of systemic infection.

\section{One major QTL governs soybean resistance to CIYVV.}

To elucidate how many loci are involved in cultivated soybean resistance to ClYVV and to determine where they are located in the genome, 64 RILs derived from the cross between TK780 and B01167 soybeans (Liu et al. 2007) were mechanically inoculated with ClYVV-No.30-GFP and were evaluated for symptoms and GFP expression. Since various symptoms were observed on the inoculated RILs, we classified them into four type groups (Fig. 6). Type 1 (score 1) had no symptoms or GFP expression on upper leaves, similar to the parental cultivated soybean TK780. Type 2 (score 2 ) rarely spread systemically prior to $28 \mathrm{dpi}$ and showed no or very weak symptoms or GFP expression. Type 3 (score 3 ) developed visible but mild vein clearing symptoms between 14 and $21 \mathrm{dpi}$, with a low but detectable level of GFP expression. Type 4 (score 4) developed severe mosaic or necrotic symptoms similar to the parental wild soybean B01167 by 14 dpi, combined with a pronounced level of GFP expression (Fig. 6A). The inoculated RILs were broadly classified into the four types; 11, 15, 16, and 17 lines were grouped into types 1 to 4 , respectively, and the other five lines could not be classified into just one type group (Supplementary Table S2).

To quantify and map the genes that contribute to the soybean resistance against CIYVV, multiple QTL model mapping was performed, using 282 markers (Liu et al. 2007) and the phenotypes of all 64 RILs. One major QTL significantly associated with the resistance (logarithm of the likelihood ratio [LOD] >2) was identified near the top arm of linkage group D1b (chromosome 2) (Fig. 6B) and had a LOD score of 15.0, accounting for $68.3 \%$ of the genetic variation. This major QTL was located between simple sequence repeat markers Satt095 and Satt558 (Liu et al. 2007) (Fig. 6B). RILs that inherited the cultivated and wild soybean genotype between markers Satt095 and Satt558 were resistant and susceptible to ClYVV, respectively, except for RILs 022 and 030. Although inheriting the cultivated soybean genotype between markers Satt095 and Satt558, these RILs were moderately susceptible to CIYVV (assigned as type 3 ) implying that other loci confer the susceptibility. Our data indicate that one major QTL, which is located on linkage group D1b, governs the resistance to ClYVV. We here designate the resistant allele at this major QTL as domestication-related resistance to ClYVV $(d-c v)$.
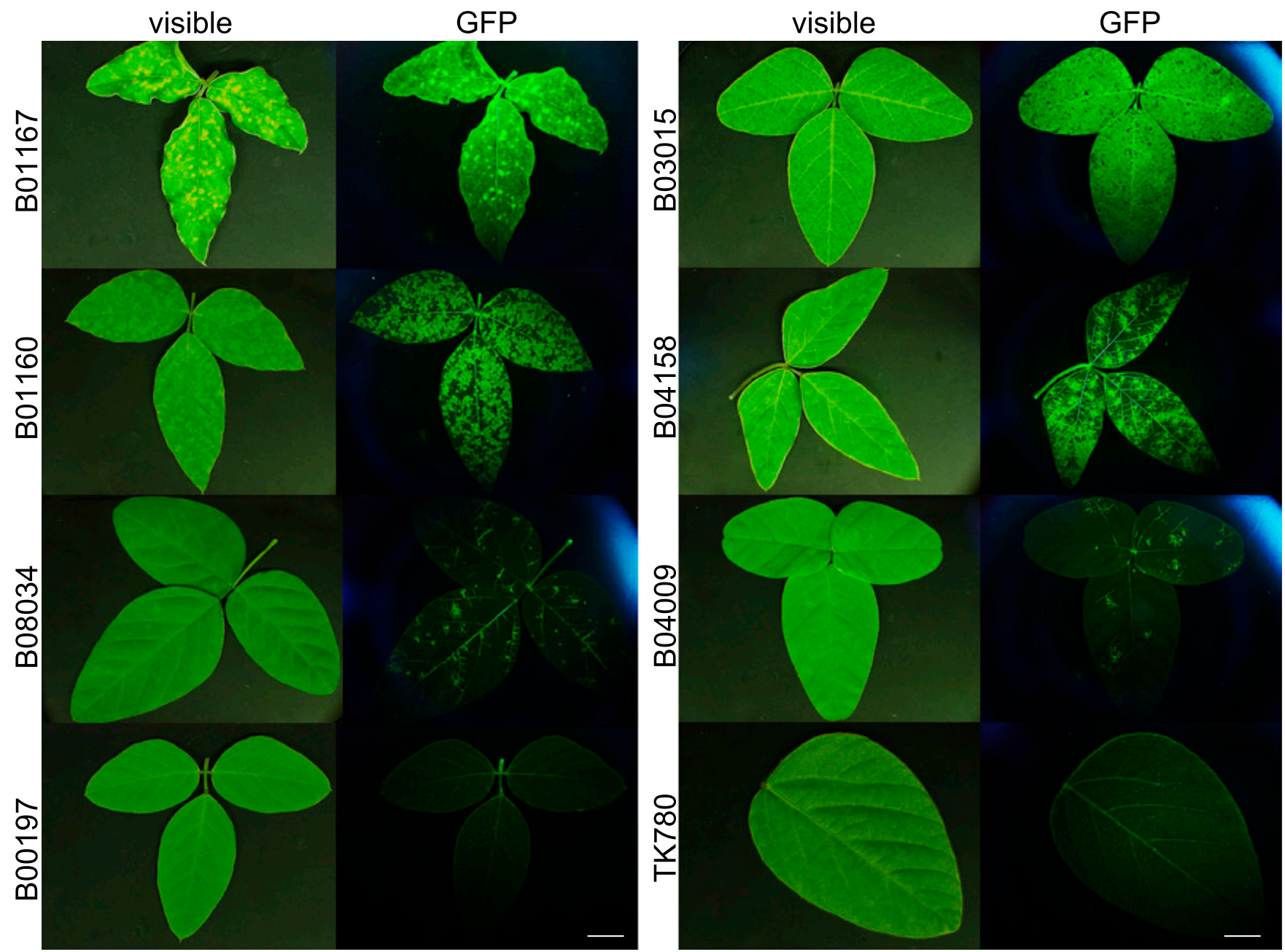

Fig. 4. Various symptoms and green fluorescent protein (GFP) signals on noninoculated leaves from wild-soybean lines (B01167, B03015, B01160, B04158, B08034, B04009, B00197) or that of cultivated soybean TK780 inoculated mechanically with sap containing clover yellow vein virus (ClYVV) isolate No. $30 \mathrm{GFP}$ are shown. Leaves were visualized, at 21 days postinoculation, for GFP expression indicating viral distribution in tissues. Inoculated leaves of B01167 and B03015 developed severe mosaic symptoms, while those of B01160 and B04158 developed vein clearing, mottle, and mosaic. Leaves of B08034 and B04009 showed very weak vein clearing; those of B00197 and Glycine max TK780 did not have any symptoms or GFP signals. Scale bars $=10 \mathrm{~mm}$. 


\section{DISCUSSION}

This study revealed differences between cultivated soybean (G. max) and its ancestor, wild soybean (G. soja), against ClYVV. Among the Glycine spp. lines tested, cultivated and wild soybeans were resistant and susceptible, respectively. A dozen of the cultivated soybeans tested expressed restricted local infection and were not infected systemically with the three ClYVV isolates used, except for cultivated soybean TK780 inoculated with CIYVV-I89-1. Even though systemically infected, TK780 soybean was still partially resistant to ClYVV-I89-1. Interestingly, the genomic sequence of ClYVV$\mathrm{Gm}$, which was isolated from naturally infected field-grown soybean plants in South Korea (Shin et al. 2014), has the highest genetic similarity to ClYVV-I89-1 among the three ClYVV isolates used in this study. However, in general ClYVV is not considered as a major pathogen of soybean because ClYVV-Gm was isolated from only two field-grown soybeans displaying mottle and mosaic among 151 plants exhibiting viral-like leaf symptoms. The study by Shin et al. (2014) was the first report implying CIYVV caused disease in South Korean soybean fields. To the best of our knowledge, there has been only one other earlier study reporting on a virus that was likely ClYVV isolated from a field-grown soybean (Jones and Diachun 1977). Contrasting susceptibility of almost all wild soybeans used in this study to ClYVV suggests that ClYVV has intrinsically been a pathogen of members of the subgenus Soja. Then, it is possible that resistance of cultivated soybeans to viruses including ClYVV has been derived from the ancestral wild soybeans by artificial selection during domestication thousands years ago.

Uncovering the molecular mechanism of nonhost resistance is important for understanding how the host range of a pathogen is determined and also for obtaining genetic resources to confer disease resistance in crops. However, in nonhost plants, the factors that are involved in the resistance are not genetically tractable if all the members of the species are resistant to a pathogen. That is probably why one or more molecular mechanisms of most types of nonhost resistance remain poorly understood. One exception is the study of the nonhost
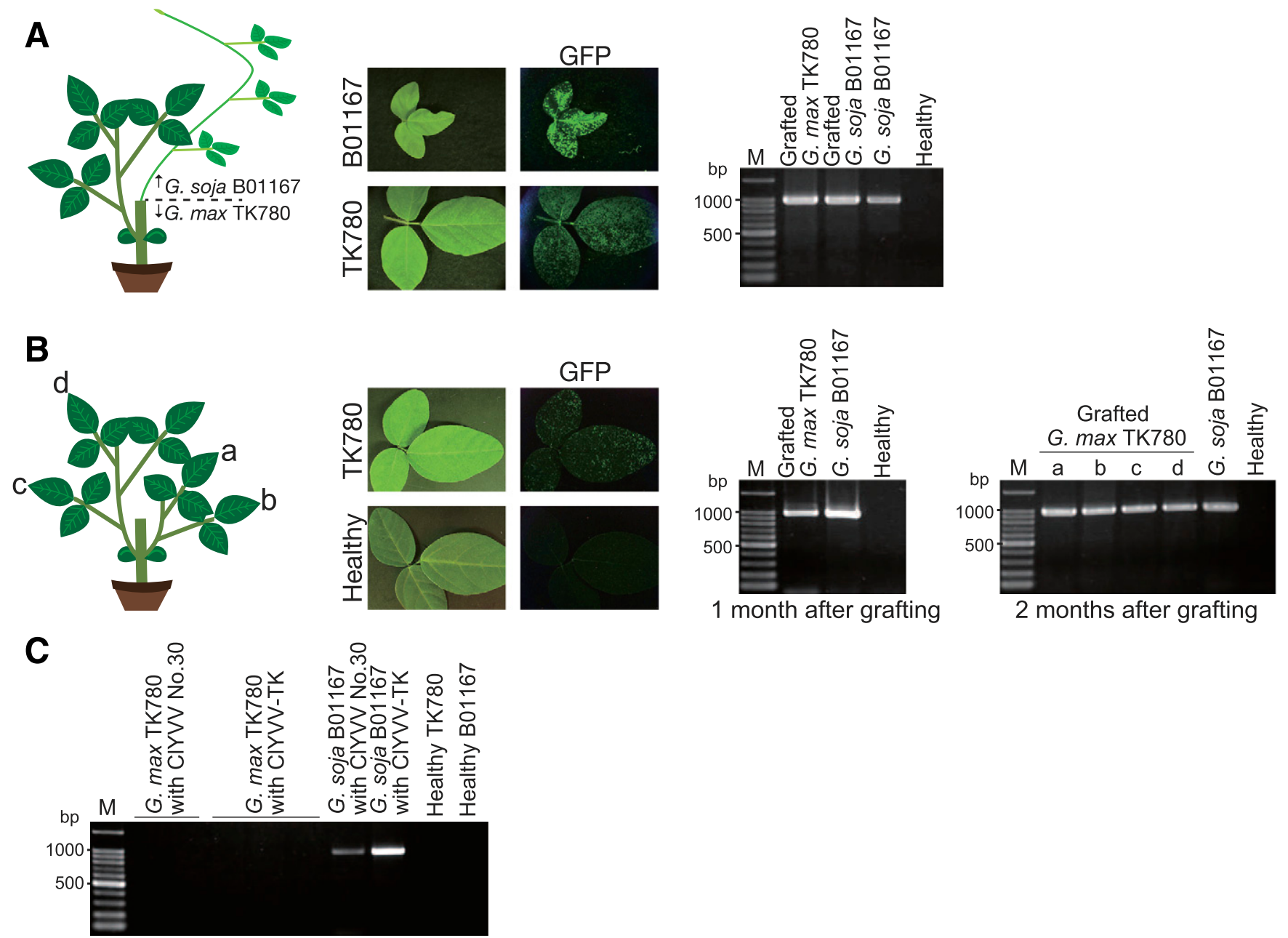

Fig. 5. Systemic infection of clover yellow vein virus isolate No. 30 green fluorescent protein (ClYVV-No.30-GFP) in leaves of cultivated soybean TK780 rootstock onto which ClYVV-No.30-GFP-infected wild soybean (B01167) (scion) was grafted. A, One week after inoculation of the seedling, ClYVV-No.30GFP-infected wild soybean B01167 scion was grafted onto cultivated soybean TK780. GFP signal derived from ClYVV infection was detected 1 month post grafting. ClYVV-No.30-GFP infection in the TK 780 rootstock (cultivated soybean) tissues was investigated by reverse transcription (RT)-PCR 1 month post grafting. B, ClYVV-infected wild soybean scion was temporarily (for 1 week) grafted onto TK 780 cultivated soybean, serving as a rootstock. GFP signal was also detected 1 month post grafting. CIYVV infection in the grafted cultivated soybean rootstock was investigated by RT-PCR 1 and 2 months post grafting. Cultivated soybean leaves at the positions indicated (a, b, c, and d) were harvested for the RT-PCR assay. C, Cultivated and wild soybean plants were inoculated with sap containing ClYVV that infected cultivated soybean (tentatively designated ClYVV-TK) (back-inoculation). One month after back-inoculation, noninoculated upper leaves of the plants were harvested and their ClYVV-TK infection was investigated by RT-PCR. 
resistance in tomato (Solanum lycopersicum) against tobacco mild green mosaic virus (TMGMV) and pepper mild mottle virus (PoMMV) (Ishibashi et al. 2009). Ishibashi et al. (2009) initially identified the protein encoded by tomato $T m-1$ that does not govern nonhost resistance but rather controls cultivarspecific semidominant resistance to tomato mosaic virus. The Tm-1-encoded protein inhibits replication of tomato mosaic virus by binding to viral replicase (Ishibashi et al. 2007). Ishibashi et al. (2009) later demonstrated that the recessive allele tm- 1 encodes the protein that governs tomato nonhost resistance against TMGMV and PMMoV via binding to and inhibiting viral replicases. Since the protein encoded by $\mathrm{tm}-1$ was easily identified using the information on its allelic Tm-1, they could create the $t m-1$ protein-expressed transgenic tobacco, for which the wild-type host is susceptible to TMGMV and PoMMV. They showed that the $t m-1$ confers resistance to these tobamoviruses in transgenic tobacco plants with the tomato $\mathrm{tm}-1$.

In our case, all the cultivated soybeans are resistant to ClYVV No. 30 and, thus, a cross between a resistant and a susceptible cultivated soybean is not possible. Because wild soybeans are susceptible to CIYVV, instead, we were able to cross a resistant cultivated soybean with a CIYVV susceptible wild soybean to generate F1, F2, and RILs. All the F1 plants were systemically infected with ClYVV-No.30-GFP, suggesting the recessive inheritance of the resistance. Inoculation tests with F2 plants support the recessive inheritance of the resistance as well. The ratio of the resistant and susceptible plants to systemic infection by ClYVV among inoculated F2 plants implied that two or more host factors are involved in the resistance. Consistently, the inoculated RILs showed varied reactions to ClYVV and were divided into four categories according to their reactions to the virus in terms of symptoms and GFP expression in the noninoculated leaves. The ratio (9/64 RILs) of the resistant plants that prevented the virus from infecting systemically was similar to that of the inoculated F2 plants. However, the QTL analysis, using 64 RILs, only detected one major peak for the LOD in soybean linkage group D1b (chromosome 2) (Fig. 6B), at which we designated the resistant allele as $d-c v$. We are now continuing a finer genetic analysis to detect one or more possible minor QTLs and identify the genes encoded on $d$ - $c v$. The involvement of one major QTL in the resistance to CIYVV and its recessive trait of inheritance supports its selection during domestication, since most beneficial traits of cultivated plants are known to be acquired by loss-of-function mutations that are recessively inherited (Ladizinsky 1985). It is known that most domestication-related traits are controlled by one or two major QTLs in soybean and other crops (Liu et al. 2007; Ross-Ibarra 2005).

Soybean cultivars possess resistant genes, including Rsv1, $R s v 3$, and $R s v 4$, against SMV, which is a major pathogen of soybean and belongs to the genus Potyvirus, similar to ClYVV (Saghai Maroof et al. 2008). The $d$-cv locus seems not related to these resistant loci because these are all dominantly inherited. Furthermore, Rsv1 and Rsv 3 are located on different chromosomes, 13 and 14, respectively, whereas that of the Rsv4 position differs from the region where the $d-c v$ is mapped by the QTL analysis (Saghai Maroof et al. 2008, 2010); $d$-cv and Rsv4 are located upstream and downstream of the marker Satt558 on chromosome 2, respectively (Fig. 6B). Considering the recessive traits of inheritance, the $d-c v$ gene is supposed to encode a co-opted factor for ClYVV infection, such as eIF4E (Andrade et al. 2009; Nakahara et al. 2010), and probably have
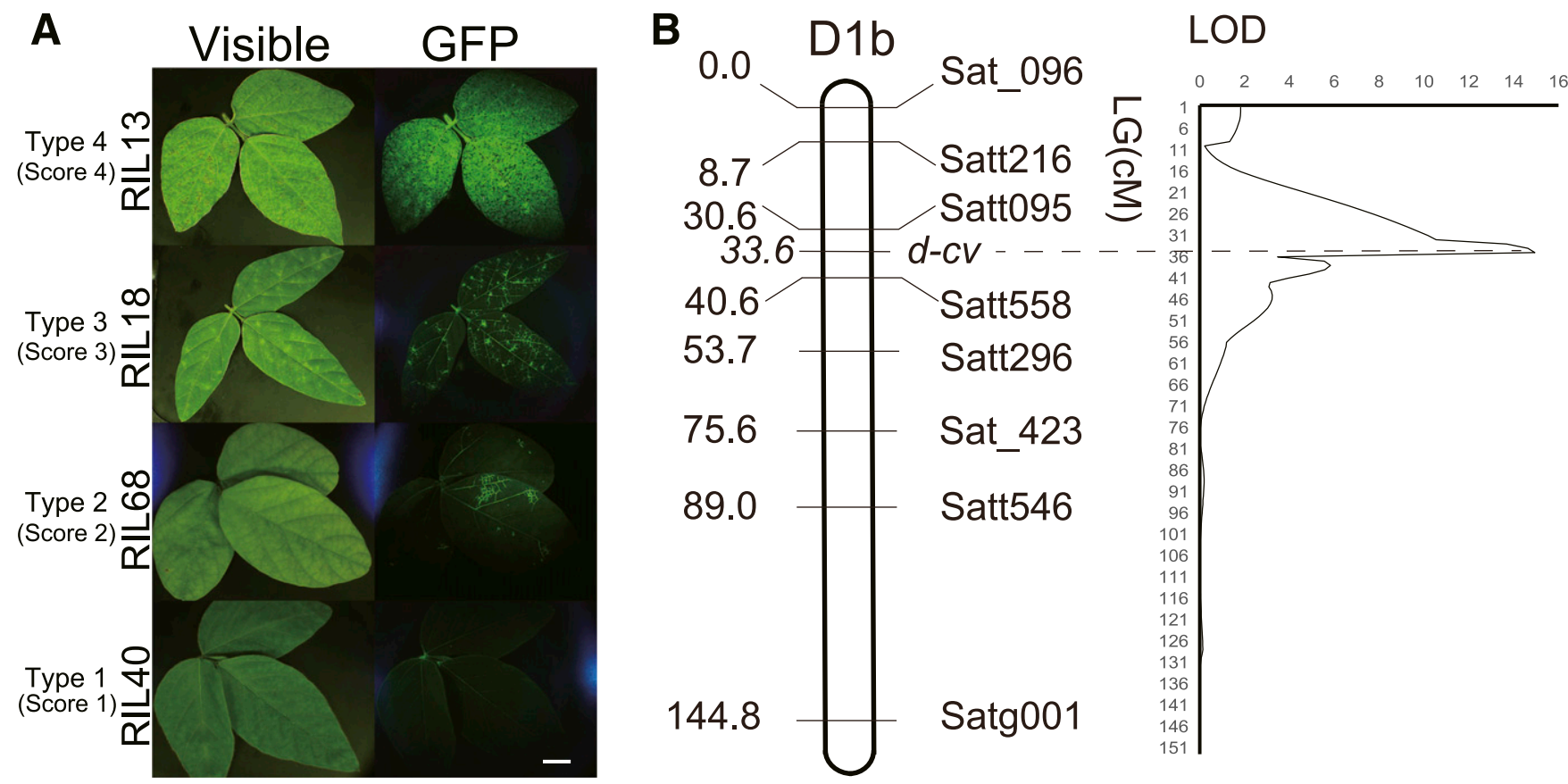

Fig. 6. Genetic elucidation of the soybean anti-clover yellow vein virus (ClYVV) resistance genes, using recombinant inbred lines (RILs). A, Phenotypes of RIL noninoculated leaves from plants mechanically inoculated with ClYVV No. 30 tagged with green fluorescent protein [ClYVV-No.30-GFP] on primary leaves. Type 1 (score 1) did not show any symptoms or GFP signals on upper noninoculated leaves, similar to the parental soybean TK780; type 2 (score 2 ) showed no or very weak symptoms or GFP signals until 28 days postinoculation (dpi); type 3 (score 3 ) developed visible but mild vein clearing symptoms with low but detectable GFP expression at $21 \mathrm{dpi}$; and type 4 (score 4) developed severe mosaic or necrotic symptoms similar to the parental wild soybean B01167 at $14 \mathrm{dpi}$ combined with pronounced levels of GFP expression. Scale bar $=1 \mathrm{~mm}$. B, To quantify and map the gene or genes contributing to cultivated soybean resistance to ClYVV, multiple quantitative trait loci (QTL) model mapping was performed using 282 markers (Liu et al. 2007 ) and the phenotypes of all 64 RILs. One major QTL ( $d$ - $c v)$ significantly associated with the resistance was located at 33.6 centimorgan (logarithm of the likelihood ratio [LOD] >2) was identified near the top arm of soybean linkage group D1b (chromosome 2); a LOD score of 14.95 accounted for $68.3 \%$ of the genetic variation. 
mutations that disrupt the function required for CIYVV systemic infection, resulting in the resistance when plants are homozygous for the $d-c v$ allele. Another possibility is that $d-c v$ encodes a negative regulator for the soybean antiviral system against ClYVV.

Our study provides data for where ClYVV infection is blocked in cultivated soybean carrying $d-c v$. In general, in order for a mechanically inoculated virus to move systemically in an inoculated plant, it must infect and multiply in initially invaded cells and moves cell-to-cell within the inoculated leaf, followed by long-distance movement (i.e., entry into vascular system, systemic spread through phloem tissue, and exit into mesophyll cells of noninoculated leaves). Systemic infection of ClYVV in soybean carrying $d-c v$ upon direct delivery into phloem tissue by graftinoculation (Fig. 5) suggests that, upon mechanical inoculation, the cultivated soybean inhibits CIYVV at infection steps prior to the systemic spread of the virus via phloem tissue. Actually, ClYVV accumulated and spread to a lesser extent in mechanically inoculated leaves of cultivated soybean than in wild soybean (Figs. 1, 2, and 3). Nevertheless, it is possible that movement of a susceptibility factor from the ClYVV-infected wild soybean scion into cultivated soybean rootstock results in enhancement of ClYVV infection, although, it should be pointed out, there is no published evidence in support of this possibility.

To further investigate how cultivated soybean inhibits systemic infection of ClYVV and whether the resistance of cultivated soybeans has been artificially selected during domestication, we need to identify not only the gene or genes at the $d-c v$ locus but also viral factors that interact with $d-c v$. P1, P3, P3N-PIPO, CI, and viral genome-linked protein of potyviruses have previously been reported as virulence determinants that interact with recessively inherited resistance factors from plants (Choi et al. 2013; Nakahara et al. 2010; TavertRoudet et al. 2012; Wang and Krishnaswamy 2012). HC-Pro, $6 \mathrm{~K} 2$, and $\mathrm{CP}$, which are involved in long-distance movement (Hipper et al. 2013), are also candidate viral factors that may interact with $d-c v$. Although ClYVV is not a major pathogen of cultivated soybean, if the gene or genes encoded by $d-c v$ is a coopted factor for CIYVV infection, it is highly likely that $d$ - $c v$, its homologs, or related genes, singly or in combination, are coopted by other potyviruses, including SMV. Therefore, uncovering the mechanism of this $d$-cv-mediated recessive resistance might contribute to molecular breeding to confer resistance to SMV in soybean cultivars as well.

\section{MATERIALS AND METHODS}

\section{Construction of CIYVV-No.30-GUS.}

To construct ClYVV-No.30-GUS, plasmid ClYVV-PstI (a gift from I. Uyeda of Hokkaido University, Japan) was used as a backbone. To use the PstI sites at positions 630 and 1,098 (numbering form the first nucleotide of the ClYVV genome) for cloning the uidA gene, the PstI site at position 9,164 was destroyed by oligonucleotide-site directed mutagenesis (Masuta et al. 2000). PrimeSTAR HS DNA polymerase Premix (Takara Bio, Madison, WI, U.S.A.) was used. All plasmid constructs were amplified and were maintained in Escherichia coli DH5 $\alpha$. Initially, the $3^{\prime}$ region of the $P 1$ cistron of CIYVV was amplified by PCR with primer C-GUS-1 and C-GUS-2 (Supplementary Table S3), using ClYVV-PstI as a template. The uidA gene was amplified with primers C-GUS-3 and CGUS-4, while SMV-N-GUS (Wang et al. 2006) served as a template. The $3^{\prime}$ region of the $P 1$ cistron and $5^{\prime}$ termini of $u i d A$ gene were merged by fusion PCR (Charlier et al. 2003). The resultant two gel-purified fragments were mixed together at the same molar ratio to serve as a template in a $50-\mu$ l reaction mixture that consisted of $200 \mathrm{ng}$ of mixed fragments, $25 \mu \mathrm{l}$ of
PrimeSTAR HS (Premix), and $0.5 \mu \mathrm{M}$ each of primers C-GUS-1 and C-GUS-4. The PCR program for the amplification reaction was as follows: one cycle of $2 \mathrm{~min}$ at $95^{\circ} \mathrm{C} ; 20 \mathrm{~s}$ at $95^{\circ} \mathrm{C}, 30 \mathrm{~s}$ at $58^{\circ} \mathrm{C}$, and $2 \mathrm{~min}$ at $72^{\circ} \mathrm{C}$ for a total of 20 cycles; followed by a final extension cycle for $10 \mathrm{~min}$ at $72^{\circ} \mathrm{C}$. The resultant amplified fragments were digested with PstI and were ligated into CIYVV No. 30 to generate CIYVV-No.30-GUS. The presence of P1 and NIa cleavage recognition sites between P1 and GUS as well as between GUS and HC-Pro, respectively, were verified by sequencing their encoded region. Furthermore, the junction of the $3^{\prime}$ region of $P 1$ cistron and $5^{\prime}$ termini of $u i d A$ gene as well as the junction between $3^{\prime}$ of uidA gene with the $5^{\prime}$ terminus of $H C$-Pro cistron in the construct were also confirmed by sequencing with primers C-531S, C-GUS-3, and C-1195a. Sequencing was done at The University of Tennessee DNA Sequencing Facility, Knoxville, TN, U.S.A., and sequences were edited using the DNA Star package and the Wisconsin package version 10.2 (Genetic Computer Group, Madison, WI, U.S.A.).

\section{Viruses, soybean genotypes, and inoculation.}

Wild soybean accessions, soybean cultivars, and RILs used in this study were obtained from LegumeBase, an integrated resource database of Lotus japonicus and G. max, or from the Genebank of the National Agriculture and Food Research Organization in Japan. Soybean genotypes (Williams [rsvl, rsv4], Essex (rsv1, rsv4), Lee68 (rsv1, rsv4), York (Rsv1), PI96983 (Rsv1), L78-379 (Rsv1), L800 (3gG2), L943 (-3gG2), and V94-5152 [Rsv4]) (Bernard et al. 1991), which show variable reactions (from extreme resistance to susceptible) to SMV strains, were used in this study. Plant materials used in this study are also listed in Table 1. The RILs (F8) used in this study were developed previously by the single seed descent method from an F2 population of a cross between TK780 (G. max parent) and B01167 (alias: Hidaka 4, G. soja parent) at Hokkaido University (Liu et al. 2007).

To establish infection with plasmid DNAs, we biolistically inoculated fully expanded primary leaves of soybean seedlings as described previously (Hajimorad et al. 2003, 2008). For mechanical inoculations, sap extract from biolistically inoculated and systemically infected leaf tissues from broad bean ( $V$. faba L.) cultivar Windsor, in $10 \mathrm{mM}$ phosphate buffer, $\mathrm{pH}$ 7.0, was applied manually to fully developed primary leaves. ClYVV-No.30-GFP, which was named pCIYVV/C3-S65T previously (Sato et al. 2003), was used to biolistically inoculate broad bean plants ( $V$. faba cv. Komazakae). Approximately $10 \mathrm{dpi}$, sap derived from the first noninoculated symptomatic leaves were used for mechanical inoculation. ClYVV-I89-1 and ClYVV-90-1 were used to inoculate broad bean plants, and sap from the first noninoculated symptomatic leaves was used as inocula. Inoculated plants were kept in a growth chamber at $22^{\circ} \mathrm{C}$ with a photoperiod of $16 \mathrm{~h}$. For segregation analysis, F1 plants were obtained by crossing wild soybean B01167 and cultivated soybean TK780. F2 plants were derived from self-pollination of $\mathrm{F} 1$ plants. These plants were inoculated with ClYVV-No.30-GFP and were incubated in a growth room as described above. For graft inoculation, primary leaves of wild soybean seedlings B01167 were mechanically inoculated with infectious sap containing ClYVV-No.30-GFP. One week postinoculation, the upper parts of wild soybean seedlings were grafted on seedlings of soybean TK780; these served as scion and rootstock, respectively.

\section{Phylogenetic analysis.}

Phylogenetic analysis done using full-length nucleotide sequences of ORFs encoding the polyproteins or deduced amino acid sequences of polyproteins. Sequence alignment was conducted by using MUSCLE (Edgar 2004). A maximum likelihood tree was inferred with substitution models and rates 
among sites that were determined using the MEGA6 package (Tamura et al. 2013). The significance of the nodes was estimated with 1,000 bootstrap replicates.

\section{Detection of CIYVV.}

Histochemical assay for GUS expression was done as described by Wen and Hajimorad (2010). Infection of wild soybean plants and cultivated soybean plants with ClYVV-No.30-GFP was monitored for GFP expression at 3,5, and 7 dpi and on systemic leaves at $21 \mathrm{dpi}$, using a fluorescence microscope system (VB7010; Keyence, Osaka, Japan) with a band-pass GFP filter (FF01520/35-25; Semrock, Rochester, NY, U.S.A.). To detect ClYVV immunologically, mouse polyclonal antibodies against $\mathrm{CP}$ of ClYVV was used at a rate of 1:1,000 in antigen-coated indirect ELISA and was probed with goat antimouse immunoglobulin $\mathrm{G}$ alkaline phosphatase conjugate (Bio-Rad, Hercules, CA, U.S.A.) at a rate of 1:5,000. ClYVV CP was also detected by western blotting as previously described (Nakahara et al. 2012), using rabbit serum containing polyclonal antibodies raised against ClYVV CP at 7 dpi for inoculated leaves and at 21 or 35 dpi for systemic leaves. For more sensitive detection of CIYVV, RT-PCR was performed at $28 \mathrm{dpi}$, using primers for the $N I b$ cistron of ClYVV: 5'-CTTTAGACCTATGATGGGC-3' (sense) and 5'GTTCAAGCCCAATTCTTTG-3' (antisense), as described previously (Choi et al. 2013).

\section{Evaluation of resistance of RIL plants to CIYVV.}

The level of resistance of each RIL plant was determined by the severity of symptoms and the level of GFP expression, monitored at $28 \mathrm{dpi}$, and separated into four types (types 1 to 4 , as described above).

\section{QTL mapping.}

The F8 generations of RILs derived from crosses between G. $\max$ and G. soja (parents), as described above, were mechanically inoculated with ClYVV-No.30-GFP, and four phenotypes were used for scoring and QTL analysis. Each type or trait (types 1 to 4 ) in response to ClYVV infection of 64 RILs was scored from 1 to 4 , and the QTL mapping was performed as described next. Marker order and distance from expected QTL of $d-c v$ were used to find the candidate QTL by composite interval mapping, implemented by MapQTL 5 (van Ooijen 2004). A total of 1,000 permutations were performed to establish the LOD thresholds at 0.05 probability (Churchill and Doerge 1994). QTLs were considered to exist only at positions where the LOD score exceeded the corresponding significance threshold.

\section{ACKNOWLEDGMENTS}

We thank H. Takagi and R. S. Nelson for insightful discussions.

\section{AUTHOR-RECOMMENDED INTERNET RESOURCE}

LegumeBase: https://www.legumebase.brc.miyazaki-u.ac.jp

\section{LITERATURE CITED}

Andrade, M., Abe, Y., Nakahara, K. S., and Uyeda, I. 2009. The cyv-2 resistance to Clover yellow vein virus in pea is controlled by the eukaryotic initiation factor 4E. J. Gen. Plant Pathol. 75:241-249.

Andrade, M., Sato, M., and Uyeda, I. 2007. Two resistance modes to Clover yellow vein virus in pea characterized by a green fluorescent proteintagged virus. Phytopathology 97:544-550.

Atsumi, G., Kagaya, U., Kitazawa, H., Nakahara, K. S., and Uyeda, I. 2009. Activation of the salicylic acid signaling pathway enhances Clover yellow vein virus virulence in susceptible pea cultivars. Mol. PlantMicrobe Interact. 22:166-175.
Atsumi, G., Suzuki, H., Miyashita, Y., Choi, S. H., Hisa, Y., Rihei, S. Shimada, R., Jeon, E. J., Abe, J., Nakahara, K. S., and Uyeda, I. 2016. P3N-PIPO, a frameshift product from the $P 3$ gene, pleiotropically determines the virulence of clover yellow vein virus in both resistant and susceptible peas. J. Virol. 90:7388-7404

Bays, D. C., Tolin, S. A., and Roane, C. W. 1986. Interactions of peanut mottle virus strains and soybean germ plasm. Phytopathology 76: 764-768.

Bernard, R. L., Nelson, R. L., and Cremeens, C. R. 1991. USDA soybean genetic collection: Isoline collection. Soybean Genet. Newsl. 18 27-57.

Bos, L., Kowalska, C., and Maat, D. Z. 1974. The identification of bean mosaic, pea yellow mosaic and pea necrosis strains of bean yellow mosaic virus. Eur. J. Plant Pathol. 80:173-191.

Campos, R. E., Bejerman, N., Nome, C., Laguna, I. G., and Rodríguez Pardina, P. 2014. Bean yellow mosaic virus in soybean from Argentina. J. Phytopathol. 162:322-325.

Charlier, N., Molenkamp, R., Leyssen, P., Vandamme, A. M., De Clercq, E., Bredenbeek, P., and Neyts, J. 2003. A rapid and convenient variant of fusionPCR to construct chimeric flaviviruses. J. Virol. Methods 108:67-74.

Choi, S. H., Hagiwara-Komoda, Y., Nakahara, K. S., Atsumi, G., Shimada, R., Hisa, Y., Naito, S., and Uyeda, I. 2013. Quantitative and qualitative involvement of P3N-PIPO in overcoming recessive resistance against Clover yellow vein virus in pea carrying the cyv1 gene. J. Virol. 87: 7326-7337.

Choi, S. H., Nakahara, K. S., Andrade, M., and Uyeda, I. 2012. Characterization of the recessive resistance gene cyv1 of Pisum sativum against Clover yellow vein virus. J. Gen. Plant Pathol. 78:269-276.

Chowda-Reddy, R. V., Sun, H., Chen, H., Poysa, V., Ling, H., Gijzen, M., and Wang, A. 2011. Mutations in the P3 protein of Soybean mosaic virus G2 isolates determine virulence on Rsv4-genotype soybean. Mol. PlantMicrobe Interact. 24:37-43.

Chung, B. Y., Miller, W. A., Atkins, J. F., and Firth, A. E. 2008. An overlapping essential gene in the Potyviridae. Proc. Natl. Acad. Sci. U.S.A. 105:5897-5902.

Churchill, G. A., and Doerge, R. W. 1994. Empirical threshold values for quantitative trait mapping. Genetics 138:963-971.

Cregan, P. B. 2008. Soybean molecular genetic diversity. Pages 17-34 in: Genetics and Genomics of Soybean. Springer, New York.

Edgar, R. C. 2004. MUSCLE: Multiple sequence alignment with high accuracy and high throughput. Nucleic Acids Res. 32:1792-1797.

Eggenberger, A. L., Hajimorad, M. R., and Hill, J. H. 2008. Gain of virulence on Rsvl-genotype soybean by an avirulent Soybean mosaic virus requires concurrent mutations in both P3 and HC-Pro. Mol. PlantMicrobe Interact. 21:931-936.

German-Retana, S., Candresse, T., Alias, E., Delbos, R.-P., and Le Gall, O. 2000. Effects of green fluorescent protein or beta-glucuronidase tagging on the accumulation and pathogenicity of a resistance-breaking Lettuce mosaic virus isolate in susceptible and resistant lettuce cultivars. Mol. Plant-Microbe Interact. 13:316-324.

Gibbs, A., and Ohshima, K. 2010. Potyviruses and the digital revolution. Annu. Rev. Phytopathol. 48:205-223.

Hagiwara-Komoda, Y., Choi, S. H., Sato, M., Atsumi, G., Abe, J., Fukuda, J., Honjo, M. N., Nagano, A. J., Komoda, K., Nakahara, K. S., Uyeda, I., and Naito, S. 2016. Truncated yet functional viral protein produced via RNA polymerase slippage implies underestimated coding capacity of RNA viruses. Sci. Rep. 6:21411.

Hajimorad, M. R., Domier, L. L., Tolin, S. A., Whitham, S. A., and Saghai Maroof, M. A. 2018. Soybean mosaic virus: A successful potyvirus with a wide distribution but restricted natural host range. Mol. Plant Pathol. 19:1563-1579.

Hajimorad, M. R., Eggenberger, A. L., and Hill, J. H. 2003. Evolution of Soybean mosaic virus-G7 molecularly cloned genome in Rsv1-genotype soybean results in emergence of a mutant capable of evading Rsv1mediated recognition. Virology 314:497-509.

Hajimorad, M. R., Eggenberger, A. L., and Hill, J. H. 2008. Adaptation of Soybean mosaic virus avirulent chimeras containing P3 sequences from virulent strains to Rsv1-genotype soybeans is mediated by mutations in HC-Pro. Mol. Plant-Microbe Interact. 21:937-946.

Hajimorad, M. R., and Hill, J. H. 2001. Rsv1-mediated resistance against Soybean mosaic virus- $\mathrm{N}$ is hypersensitive response-independent at inoculation site, but has the potential to initiate a hypersensitive response-like mechanism. Mol. Plant-Microbe Interact. 14:587-598.

Hayes, A. J., Jeong, S. C., Gore, M. A., Yu, Y. G., Buss, G. R., Tolin, S. A., and Maroof, M. A. 2004. Recombination within a nucleotide-bindingsite/leucine-rich-repeat gene cluster produces new variants conditioning resistance to soybean mosaic virus in soybeans. Genetics 166 493-503. 
Hill, J. H., and Whitham, S. A. 2014. Control of virus diseases in soybeans. Adv. Virus Res. 90:355-390.

Hipper, C., Brault, V., Ziegler-Graff, V., and Revers, F. 2013. Viral and cellular factors involved in Phloem transport of plant viruses. Front. Plant Sci. 4:154.

Ilut, D. C., Lipka, A. E., Jeong, N., Bae, D. N., Kim, D. H., Kim, J. H., Redekar, N., Yang, K., Park, W., Kang, S. T., Kim, N., Moon, J. K., Saghai Maroof, M. A., Gore, M. A., and Jeong, S. C. 2016. Identification of haplotypes at the Rsv4 genomic region in soybean associated with durable resistance to soybean mosaic virus. Theor. Appl. Genet. 129:453-468.

Ishibashi, K., Masuda, K., Naito, S., Meshi, T., and Ishikawa, M. 2007. An inhibitor of viral RNA replication is encoded by a plant resistance gene. Proc. Natl. Acad. Sci. U.S.A. 104:13833-13838.

Ishibashi, K., Naito, S., Meshi, T., and Ishikawa, M. 2009. An inhibitory interaction between viral and cellular proteins underlies the resistance of tomato to nonadapted tobamoviruses. Proc. Natl. Acad. Sci. U.S.A. 106: 8778-8783.

Ivanov, K. I., Eskelin, K., Lõhmus, A., and Mäkinen, K. 2014. Molecular and cellular mechanisms underlying potyvirus infection. J. Gen. Virol. 95:1415-1429.

Jiang, S., Lu, Y., Li, K., Lin, L., Zheng, H., Yan, F., and Chen, J. 2014. Heat shock protein 70 is necessary for Rice stripe virus infection in plants. Mol. Plant Pathol. 15:907-917.

Jones, R. T., and Diachun, S. 1977. Serologically and biologically distinct bean yellow mosaic-virus strains. Phytopathology 67:831-838.

Khatabi, B., Fajolu, O. L., Wen, R. H., and Hajimorad, M. R. 2012. Evaluation of North American isolates of Soybean mosaic virus for gain of virulence on $R s v$-genotype soybeans with special emphasis on resistancebreaking determinants on Rsv4. Mol. Plant Pathol. 13:1077-1088.

Ladizinsky, G. 1985. Founder effect in crop-plant evolution. Econ. Bot. 39: 191-199.

Liu, B., Fujita, T., Yan, Z. H., Sakamoto, S., Xu, D., and Abe, J. 2007. QTL mapping of domestication-related traits in soybean (Glycine max). Ann. Bot. 100:1027-1038.

Lu, B.-R. 2004. Conserving biodiversity of soybean gene pool in the biotechnology era. Plant Species Biol. 19:115-125.

Masuta, C., Yamana, T., Tacahashi, Y., Uyeda, I., Sato, M., Ueda, S., and Matsumura, T. 2000. Development of clover yellow vein virus as an efficient, stable gene-expression system for legume species. Plant J. 23: 539-546.

Miyashita, Y., Atsumi, G., and Nakahara, K. S. 2016. Trade-offs for viruses in overcoming innate immunities in plants. Mol. Plant-Microbe Interact. 29:595-598.

Nakahara, K. S., Masuta, C., Yamada, S., Shimura, H., Kashihara, Y., Wada, T. S., Meguro, A., Goto, K., Tadamura, K., Sueda, K., Sekiguchi, T., Shao, J., Itchoda, N., Matsumura, T., Igarashi, M., Ito, K., Carthew, R. W., and Uyeda, I. 2012. Tobacco calmodulin-like protein provides secondary defense by binding to and directing degradation of virus RNA silencing suppressors. Proc. Natl. Acad. Sci. U.S.A. 109:10113-10118.

Nakahara, K. S., Shimada, R., Choi, S. H., Yamamoto, H., Shao, J., and Uyeda, I. 2010. Involvement of the P1 cistron in overcoming eIF4Emediated recessive resistance against Clover yellow vein virus in pea. Mol. Plant-Microbe Interact. 23:1460-1469.

Olspert, A., Chung, B. Y., Atkins, J. F., Carr, J. P., and Firth, A. E. 2015. Transcriptional slippage in the positive-sense RNA virus family Potyviridae. EMBO Rep. 16:995-1004.

Ravelo, G., Kagaya, U., Inukai, T., Sato, M., and Uyeda, I. 2007. Genetic analysis of lethal tip necrosis induced by Clover yellow vein virus infection in pea. J. Gen. Plant Pathol. 73:59-65.

Rodamilans, B., Valli, A., Mingot, A., San León, D., Baulcombe, D., López-Moya, J. J., and García, J. A. 2015. RNA polymerase slippage as a mechanism for the production of frameshift gene products in plant viruses of the Potyviridae family. J. Virol. 89:6965-6967.

Ross-Ibarra, J. 2005. Quantitative trait loci and the study of plant domestication. Genetica 123:197-204.

Saghai Maroof, M. A., Tucker, D. M., Skoneczka, J. A., Bowman, B. C., Tripathy, S., and Tolin, S. A. 2010. Fine mapping and candidate gene discovery of the soybean mosaic virus resistance gene, Rsv4. Plant Genome 3:14-22.

Saghai Maroof, M. A., Tucker, D. M., and Tolin, S. A. 2008. Genomics of viral-soybean interactions. Page293-319 in: Genetics and Genomics of Soybean. Springer, New York.
Sasaya, T., Shimizu, T., Nozu, Y., Nishiguchi, M., Inouye, N., and Koganezawa, H. 1997. Biological, serological, and molecular variabilities of clover yellow vein virus. Phytopathology 87:1014-1019.

Sato, M., Masuta, C., and Uyeda, I. 2003. Natural resistance to Clover yellow vein virus in beans controlled by a single recessive locus. Mol. Plant-Microbe Interact. 16:994-1002.

Seo, J. K., Lee, S. H., and Kim, K. H. 2009. Strain-specific cylindrical inclusion protein of soybean mosaic virus elicits extreme resistance and a lethal systemic hypersensitive response in two resistant soybean cultivars. Mol. Plant-Microbe Interact. 22:1151-1159.

Shin, J. C., Kim, M. K., Kwak, H. R., Choi, H. S., Kim, J. S., Park, C. Y., and Cha, B. J. 2014. First Report of Clover yellow vein virus on Glycine max in Korea. Plant Dis. 98:1283.

Suh, S. J., Bowman, B. C., Jeong, N., Yang, K., Kastl, C., Tolin, S. A., Maroof, M. A. S., and Jeong, S. C. 2011. The Rsv3 locus conferring resistance to Soybean mosaic virus is associated with a cluster of coiledcoil nucleotide-binding leucine-rich repeat genes. Plant Genome 4:55-64.

Tamura, K., Stecher, G., Peterson, D., Filipski, A., and Kumar, S. 2013. MEGA6: Molecular evolutionary genetics analysis version 6.0. Mol Biol. Evol. 30:2725-2729.

Tavert-Roudet, G., Abdul-Razzak, A., Doublet, B., Walter, J., Delaunay, T., German-Retana, S., Michon, T., Le Gall, O., and Candresse, T. 2012. The $\mathrm{C}$ terminus of lettuce mosaic potyvirus cylindrical inclusion helicase interacts with the viral $\mathrm{VPg}$ and with lettuce translation eukaryotic initiation factor 4E. J. Gen. Virol. 93:184-193.

Tracy, S. L., Frenkel, M. J., Gough, K. H., Hanna, P. J., and Shukla, D. D. 1992. Bean yellow mosaic, clover yellow vein, and pea mosaic are distinct potyviruses: Evidence from coat protein gene sequences and molecular hybridization involving the $3^{\prime}$ non-coding regions. Arch. Virol. 122:249-261.

Uyeda, I., Takahashi, T., and Shikata, E. 1991. Relatedness of the nucleotide sequence of the 3 '-terminal region of clover yellow vein potyvirus RNA to bean yellow mosaic potyvirus RNA. Intervirology 32:234-245.

van Ooijen, J. W. 2004. MapQTL 5 software for the mapping quantitative trait loci in experimental populations. Plant Research International, Wageningen, The Netherlands.

Wang, A., and Krishnaswamy, S. 2012. Eukaryotic translation initiation factor 4E-mediated recessive resistance to plant viruses and its utility in crop improvement. Mol. Plant Pathol. 13:795-803.

Wang, L., Eggenberger, A., Hill, J., and Bogdanove, A. J. 2006. Pseudomonas syringae effector $a v r B$ confers soybean cultivar-specific avirulence on Soybean mosaic virus adapted for transgene expression but effector avrPto does not. Mol. Plant-Microbe Interact. 19: 304-312.

Wang, Y., Khatabi, B., and Hajimorad, M. R. 2015. Amino acid substitution in P3 of Soybean mosaic virus to convert avirulence to virulence on $R s v 4$-genotype soybean is influenced by the genetic composition of P3. Mol. Plant Pathol. 16:301-307.

Wei, T., Zhang, C., Hong, J., Xiong, R., Kasschau, K. D., Zhou, X., Carrington, J. C., and Wang, A. 2010. Formation of complexes at plasmodesmata for potyvirus intercellular movement is mediated by the viral protein P3N-PIPO. PLoS Pathog. 6:e1000962.

Wen, R. H., and Hajimorad, M. R. 2010. Mutational analysis of the putative pipo of soybean mosaic virus suggests disruption of PIPO protein impedes movement. Virology 400:1-7.

Wen, R. H., Khatabi, B., Ashfield, T., Saghai Maroof, M. A., and Hajimorad, M. R. 2013. The HC-Pro and P3 cistrons of an avirulent Soybean mosaic virus are recognized by different resistance genes at the complex Rsv1 locus. Mol. Plant-Microbe Interact. 26:203-215.

Whitham, S. A., Qi, M., Innes, R. W., Ma, W., Lopes-Caitar, V., and Hewezi, T. 2016. Molecular soybean-pathogen interactions. Annu. Rev. Phytopathol. 54:443-468.

Wilson, R. F. 2008. Soybean: Market driven research needs. Page 3-15 in: Genetics and Genomics of Soybean. Springer, New York.

Zhang, C., Hajimorad, M. R., Eggenberger, A. L., Tsang, S., Whitham, S. A., and Hill, J. H. 2009. Cytoplasmic inclusion cistron of Soybean mosaic virus serves as a virulence determinant on Rsv3-genotype soybean and a symptom determinant. Virology 391:240-248.

Zhou, G. C., Wu, X. Y., Zhang, Y. M., Wu, P., Wu, X. Z., Liu, L. W., Wang, Q., Hang, Y. Y., Yang, J. Y., Shao, Z. Q., Wang, B., and Chen, J. Q. 2014. A genomic survey of thirty soybean-infecting bean common mosaic virus (BCMV) isolates from China pointed BCMV as a potential threat to soybean production. Virus Res. 191:125-133. 